\title{
Using caffeoyl pyrrolidine derivative LY52, a potential inhibitor of matrix metalloproteinase-2, to suppress tumor invasion and metastasis
}

\author{
XIAN-JUN QU ${ }^{1}$, YUN-XIA YUAN ${ }^{1}$, ZHI-GANG TIAN ${ }^{1}$, WEN-FANG XU ${ }^{1}$, \\ MING-HUI CHEN $^{1}$, SHU-XIANG CUI ${ }^{2}$, QIAN GUO $^{2}$, RUOYAN GAI $^{3}$, \\ MASATOSHI MAKUUCHI ${ }^{3}$, MUNEHIRO NAKATA $^{1,4}$ and WEI TANG ${ }^{1,3}$ \\ ${ }^{1}$ School of Pharmaceutical Sciences, Shandong University; ${ }^{2}$ Shandong Academy of Medical \\ Sciences, Jinan, Shandong, P.R. China; ${ }^{3}$ Hepato-Biliary-Pancreatic Surgery Division, \\ Department of Surgery, Graduate School of Medicine, the University of Tokyo, \\ Tokyo, ${ }^{4}$ Department of Applied Biochemistry, Tokai University, Kanagawa, Japan
}

Received May 22, 2006; Accepted July 17, 2006

\begin{abstract}
LY52 is a caffeoyl pyrrolidine derivative designed to fit the $S_{1}^{\prime}$ active pocket of gelatinases that act in tumor invasion and metastasis. Herein, we examined the effects of LY52 on expression of matrix metalloproteinase (MMP)-2 expression in human breast cancer MDA-MB-231 cells and on in vitro invasion and in vivo metastasis. LY52 significantly blocked MMP-2 activity as evidenced by a decrease in the degradation of succinylated gelatin. Gelatin zymography analysis showed that LY52 $(0.1-200 \mu \mathrm{g} / \mathrm{ml})$ inhibited expression of active MMP-2 in concanavalin A-stimulated MDA-MB-231 cells. Inhibition of MMP-2 expression was also observed in tissue of tumor xenografts in mice that were orally administered LY52 (25 or $100 \mathrm{mg} / \mathrm{kg}$ ). Furthermore, LY52 displayed an inhibitory effect on in vitro invasion of MDA-MB-231 cells and pulmonary metastasis of B16F10 murine melanoma cells in mice without significant toxic effects. These results suggest that LY52 is a potential MMP-2 inhibitor that may effectively suppress tumor invasion and metastasis.
\end{abstract}

\section{Introduction}

Gelatinases including matrix metalloproteinase (MMP)-2 and -9 play an important role in the degradation of basement

Correspondence to: Dr Wei Tang, Hepato-Biliary-Pancreatic Surgery Division, Department of Surgery, Graduate School of Medicine, The University of Tokyo, 7-3-1 Hongo, Bunkyo-ku, Tokyo 113-8655, Japan

E-mail: tang-sur@h.u-tokyo.ac.jp

Key words: caffeoyl pyrrolidine derivative, LY52, matrix metalloproteinase-2, tumor invasion, metastasis membrane type IV collagen, which is associated with tumor cell invasion and metastasis $(1,2)$. Therefore, regulation of gelatinases is crucial in inhibiting tumor invasion and metastasis. Three-dimensional structural analyses of MMP molecules showed that the $S_{1}^{\prime}$ active pocket in MMP-2 and -9 is deeper than that of other types of MMPs such as MMP-3 (3-6). This property provides a helpful clue for constructing gelatinase-specific inhibitors via structure-based design strategies.

In previous studies, we constructed a series of caffeoyl pyrrolidine derivatives, which were designed based on a lead MMP inhibitor CGS27023A (7), to fit the deeper $S^{\prime}{ }_{1}$ pocket in the gelatinase molecule $(8,9)$. We then found that some of the compounds were able to inhibit gelatinase activity in vitro and pulmonary metastasis of mice $\mathrm{H}_{22}$ tumor cells in vivo $(8,9)$. LY52 is one of these caffeoyl pyrrolidine derivatives that display a substantial potential inhibitory effect on gelatinase (8). In this study, we describe the inhibitory effects of LY52 on the in vitro and in vivo expression of MMP-2 in human breast cancer cell line MDA-MB-231, which is known to express latent MMP-2. We also describe suppression by LY52 of in vitro invasion and in vivo metastasis of tumor cells.

\section{Materials and methods}

LY52. Caffeoyl pyrrolidine derivative LY52 (Fig. 1) was synthesized from 4-L-hydroxyproline through a sequence reaction including methylation, esterification, condensation, mesylation, $\mathrm{S}_{\mathrm{N}} 2$ reaction upon treatment with sodium azide, hydrogenation over $5 \% \mathrm{Pd}-\mathrm{C} / \mathrm{CaCO}_{3}$, acylation, and ester exchange upon treatment with hydroxylamine (8). The compound was dissolved in dimethylsulfoxide for in vitro assay and in 5\% amylum for in vivo study.

Cell line. The human breast cancer cell line MDA-MB-231, which expresses mesenchymal intermediate filament protein vimentin $\left(\mathrm{VIM}^{+}\right)$(10), was obtained from the Chinese National Cancer Research Center (Beijing, P.R. China). Murine 


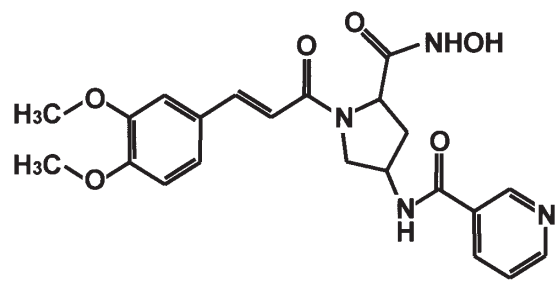

Figure 1. Structure of LY52.

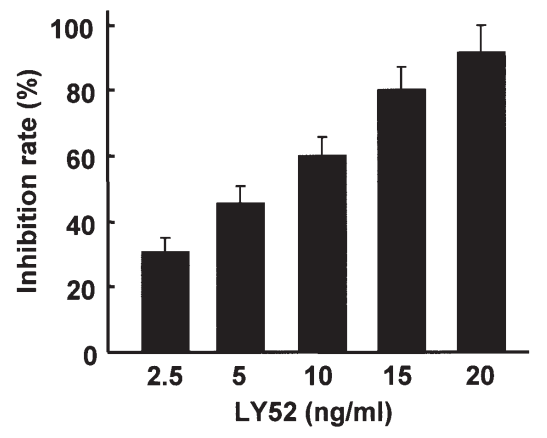

Figure 2. Rates of inhibition of MMP-2 activity by LY52. Proteolysis of succinylated gelatin by MMP-2 was evaluated in the presence of various concentrations of LY52 as described in Materials and methods. Data are mean $\pm \operatorname{SD}(n=3)$.

(Beijing, P.R. China). Cells were maintained RPMI-1640 supplemented with $10 \%$ (v/v) heat-inactivated fetal bovine serum, penicillin-streptomycin (100 IU/ml-100 $\mu \mathrm{g} /$ $\mathrm{ml}), 2 \mathrm{mM}$ glutamine, and $10 \mathrm{mM}$ Hepes buffer at $37^{\circ} \mathrm{C}$ in a humid atmosphere $\left(5 \% \mathrm{CO}_{2}-95 \%\right.$ air $)$ and were harvested by brief incubation in $0.02 \%$ EDTA-PBS. Cell viability was assessed by 3-[4,5-dimethylthiazol-2-yl]-2,5-diphenyltetrazolium bromide (MTT) assay as described elsewhere (11).

Animals. Female Balb/c athymic (nu+/nu+) mice, 4-6 weeks of age, and female C57/BL6 mice, 5-6 weeks of age, were purchased from the Animal Experiment Central of Beijing (Beijing, P.R. China). The research protocol was approved in accordance with the institutional guidelines of the Animal Care and Use Committee at Shandong University. Animals were housed under pathogen-free conditions.

Succinylated gelatin assay. MMP-2 activity was estimated by succinylated gelatin assay in a 96-well flat-bottom microtiter plate (12). The reaction mixture (total $150 \mu \mathrm{l}$ ) contained $80 \mathrm{ng}$ of MMP-2 (Sigma-Aldrich, St. Louis, MO, USA), $200 \mu \mathrm{g}$ of succinylated gelatin (Sigma-Aldrich), $50 \mu \mathrm{g}$ of p-aminophenylmercuric acetate (APMA, Sigma-Aldrich), and various doses of LY52. The reactions were carried out at $37^{\circ} \mathrm{C}$ for $30 \mathrm{~min}$. Trinitrobenzene sulfonic acid (50 $\mu 1$ of $0.03 \%)$ (TNBSA, Sigma-Aldrich) were then added to the reaction mixture and allowed to incubate at room temperature for $20 \mathrm{~min}$. Absorbance at $450 \mathrm{~nm}$ of each reaction mixture was determined using a ThermOmax microplate reader (Molecular Devices, Sunnyvale, CA, USA). The inhibitory rate (\%) was evaluated by comparing the relative activity in the presence and absence of LY52.

SDS-PAGE gelatin zymography. MMP-2 expression in MDA-MB-231 cells was analyzed by SDS-PAGE gelatin zymography $(13,14)$. Briefly, cells were cultured $\left(1 \times 10^{5}\right.$ cells/ $0.5 \mathrm{ml}$ ) in 24-well plates and then treated with concanavalin A (Con A, $25 \mu \mathrm{g} / \mathrm{ml}$, Sigma-Aldrich) to induce MMP-2 activation $(13,15)$ in the presence of various concentrations of LY52 for $24 \mathrm{~h}$ at $37^{\circ} \mathrm{C}$ in a humidified $5 \% \mathrm{CO}_{2}-95 \%$ atmosphere. The supernatant $(10 \mu \mathrm{l})$ was subjected to electrophoresis on $10 \%$ SDS-PAGE co-polymerized with $1 \mathrm{mg} / \mathrm{ml}$ gelatin as a substrate. After electrophoresis was complete, the gel was washed with $2 \%$ Triton X-100 solution to remove SDS and then incubated in activation buffer $(50 \mathrm{mM}$ Tris- $\mathrm{HCl}, \mathrm{pH} 7.4$, containing $5 \mathrm{mM} \mathrm{CaCl}{ }_{2}, 0.5 \mu \mathrm{M} \mathrm{ZnCl}_{2}$ ) for $20 \mathrm{~h}$ at $37^{\circ} \mathrm{C}$. Gels were then stained with $0.05 \%$ Coomassie brilliant blue
R-250 and destained in 10\% acetic acid. Unstained bands corresponding to active MMP-2 were quantified by densitometry using an electrophoresis image analysis system (FR980, Shanghai Furi Science \& Technology, Shanghai, P.R. China).

Immunohistochemistry for MMP-2 in tumor xenografts. MDAMB-231 cells $\left(1 \times 10^{7}\right)$ were suspended in $100 \mu 1$ of matrigel (Collaborative Biomedical, Bedford, MA, USA) and were injected subcutaneously into the right anterior flank of Balb/c athymic (nu+/nu+) female mice (16). The mice were then orally administered 0,25 , or $100 \mathrm{mg} / \mathrm{kg}$ of LY52 in $0.5 \mathrm{ml}$ of amylum. After 30 days, tumor tissues were subjected to immunohistochemical staining. Briefly, 4- $\mu$ m-thick sections were cut from paraffin-embedded tissue blocks, deparaffinized, and dehydrated using a graded series of ethanol solutions. Endogenous peroxidase activity was blocked with $3 \% \mathrm{H}_{2} \mathrm{O}_{2}$ / PBS for $8 \mathrm{~min}$. The sections were incubated with rabbit polyclonal antibody against MMP-2 (1:100 solution, Sc-10736, Santa Cruz Biotechnology, Santa Cruz, CA, USA) for $60 \mathrm{~min}$ at room temperature and then incubated with secondary antibody (peroxidase-conjugated Affinipure goat anti-rabbit IgG, ZB-2301, Santa Cruz Biotechnology) for 60 min. 3,3'Diaminobenzidine was used as the chromogen, and hematoxylin was used as a counterstain (17). The stained cells were counted in a total of 5 microscopical fields. The results were expressed as a ratio to the control tumor in at least 3 different mice in one group.

Invasion assay in vitro. A 24-well transwell chamber was used to evaluate the motility and invasive ability of MDAMB-231 cells in vitro (18). The upper surface of polycarbonate filters with $8 \mu \mathrm{m}$ pores was coated with $100 \mu \mathrm{g}$ of matrigel. The cells were pre-incubated with different doses of LY52 for $16 \mathrm{~h}$ in the presence of Con A $(25 \mu \mathrm{g} / \mathrm{ml})$ at $37^{\circ} \mathrm{C}$ in a $\mathrm{CO}_{2}$ incubator. The cells were then detached and the cell suspension $\left(1 \times 10^{5}\right.$ cells $\left./ 100 \mu 1\right)$ was placed in the upper chambers. The lower chambers were filled with $600 \mu \mathrm{l}$ of RPMI-1640 medium containing 1\% BSA. After $24 \mathrm{~h}$ of incubation at $37^{\circ} \mathrm{C}$ under optimal conditions, the filters were fixed with $10 \%$ buffered formalin and stained with hematoxylin. Cells on the upper surface of the filter were completely removed by wiping them away with a cotton swab. The number of cells that had invaded through the matrigel and 


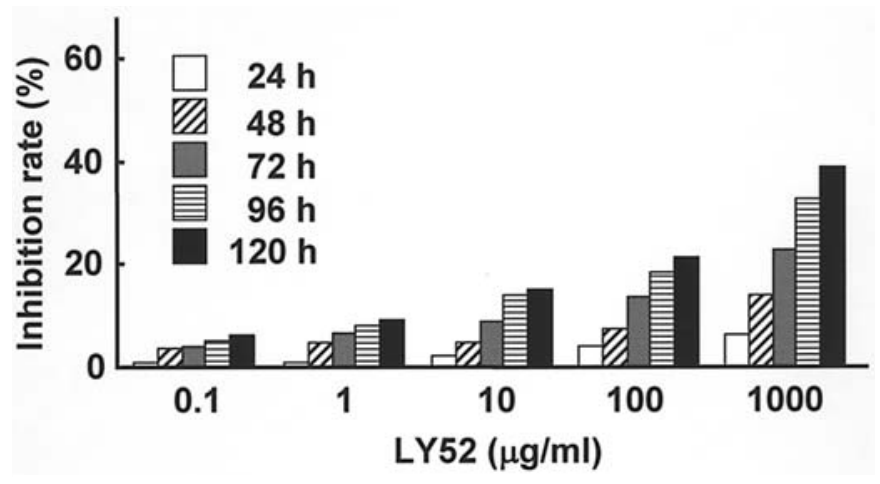

Figure 3. Effects of LY52 on MDA-MB-231 cell growth. Cells were cultured in the presence of LY52 $(0.1,1,10,100$ and $1000 \mu \mathrm{g} / \mathrm{ml})$ for up to 120 h. Cell growth was evaluated by MTT assay. Data are mean $\pm \operatorname{SD}(n=3)$.

reached the lower surface of the filter was counted in five random microscopic fields per filter at a magnification of x200. Each assay was performed in triplicate and repeated twice.

Metastasis assay in vivo. Anti-metastasis activity of LY52 was assessed using a B16F10 murine melanoma model in vivo (19). The suspension of $1 \times 10^{4} \mathrm{~B} 16 \mathrm{~F} 10$ cells in $0.2 \mathrm{ml}$ of saline was intravenously injected into the tail vein of C57BL/6 mice. Simultaneously, the mice were orally administered $0,25,50$, or $100 \mathrm{mg} / \mathrm{kg}$ of LY52 in $0.5 \mathrm{ml}$ of amylum for 3 consecutive weeks. Carboxylates (MMPs inhibitors, $100 \mathrm{mg} / \mathrm{kg}$ ) were administered orally as a positive control (20). Mice were sacrificed and the lungs were fixed in Bouin's solution. The number of metastatic nodules present over the entire surface of the five lobes of the lung was counted under a microscope.

\section{Results}

Effects of LY52 on MMP-2 activity. We first examined the effect of LY52 on MMP-2 activity by means of succinylated gelatin assay. As shown in Fig. 2, the degradation of succinylated gelatin by MMP-2 was clearly inhibited by LY52 in a dose-dependent manner. The $\mathrm{IC}_{50}$ was $8.9 \mathrm{ng} / \mathrm{ml}$.

Effects of LY52 on cell growth. The effects of LY52 on MDAMB-231 cell growth were examined. The cells were treated with LY52 $(0.1-1000 \mu \mathrm{g} / \mathrm{ml})$ for up to $120 \mathrm{~h}$ and then the rate of cell growth inhibition was evaluated based on the viable cell number as estimated by MTT assay. As shown in Fig. 3, LY52 does not have a significant anti-proliferative effect on MDA-MB-231 cells in shorter incubation periods, although a dose-dependent anti-proliferative effect was observed in longer incubation periods. In each incubation period, evident cytotoxicity of LY52 was not observed, as verified by staining for viability using trypan blue (data not shown). Therefore, in subsequent experiments where MDA-MB-231 cells were treated with LY52, the incubation periods were set within $24 \mathrm{~h}$ regardless of the concentration of LY52.

Inhibition of active MMP-2 expression in MDA-MB-231 cells. Gelatin zymography was performed to evaluate the inhibitory effect of LY52 on active MMP-2 expression in the

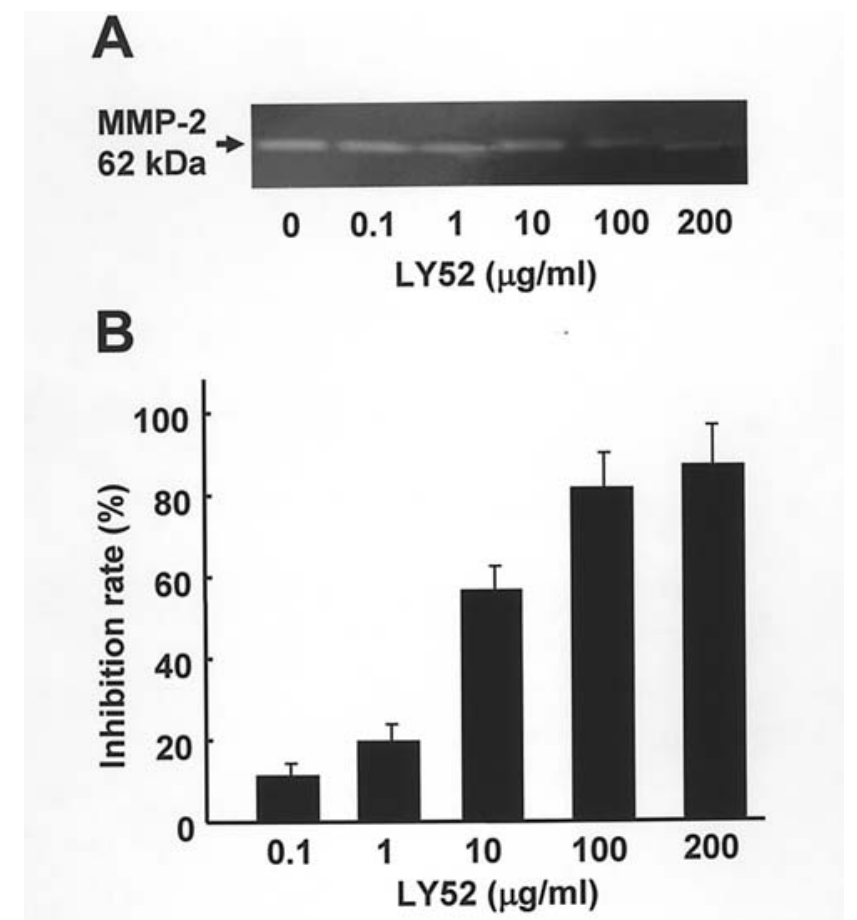

Figure 4. Inhibition of active MMP-2 expression in MDA-MB-231 cells by LY52 in vitro. Cells were exposed to various concentrations of LY52 for $24 \mathrm{~h}$. Expression of active MMP-2 in the medium was evaluated by SDSPAGE gelatin zymography (A) and the inhibition rates were estimated by densitometric quantification of the unstained bands (B). Data are mean \pm SD $(n=3)$

supernatants of MDA-MB-231 cell cultures. As shown in Fig. 4A, active MMP-2 was detected in the gel around a position at a molecular weight of $62 \mathrm{kDa}$. The level of expression was clearly suppressed by LY52 in a dosedependent manner (Fig. 4B). The $\mathrm{IC}_{50}$ was $\sim 7.5 \mu \mathrm{g} / \mathrm{ml}$.

Inhibition of MMP-2 expression in tumor xenografts. The effects of orally administered LY52 on MMP-2 expression in MDA-MB-231 cells subcutaneously transplanted in nude mice were examined immunohistochemically. As shown in Fig. 5, administration of LY52 effectively suppressed MMP-2 expression in the tumor xenografts in a dose-dependent manner. The rates of inhibition by 25 and $100 \mathrm{mg} / \mathrm{kg}$ of LY52 were 32.3 and $65.2 \%$, respectively, without weight loss in the mice (data not shown).

Inhibition of the invasive ability of $M D A-M B-231$ cells. The effects of LY52 on invasion and migration of Con A-activated MDA-MB-231 cells were examined in a 24-well transwell chamber. As shown in Fig. 6A, the activated MDA-MB-231 cells displayed a high invasive capacity, crossing the uniform layer of matrigel-coated filters; the invasive potential of the cells was clearly diminished by LY52. The inhibition by LY52 occurred in a dose-dependent manner with $\mathrm{IC}_{50}$ of $\sim 7.1 \mu \mathrm{g} / \mathrm{ml}$ (Fig. 6B).

Inhibition of pulmonary metastasis of B16F10 melanoma cells in mice. We also evaluated the ability of LY52 to inhibit tumor metastasis by using metastatic B16F10 murine melanoma cells instead of MDA-MB-231 cells. As shown in 

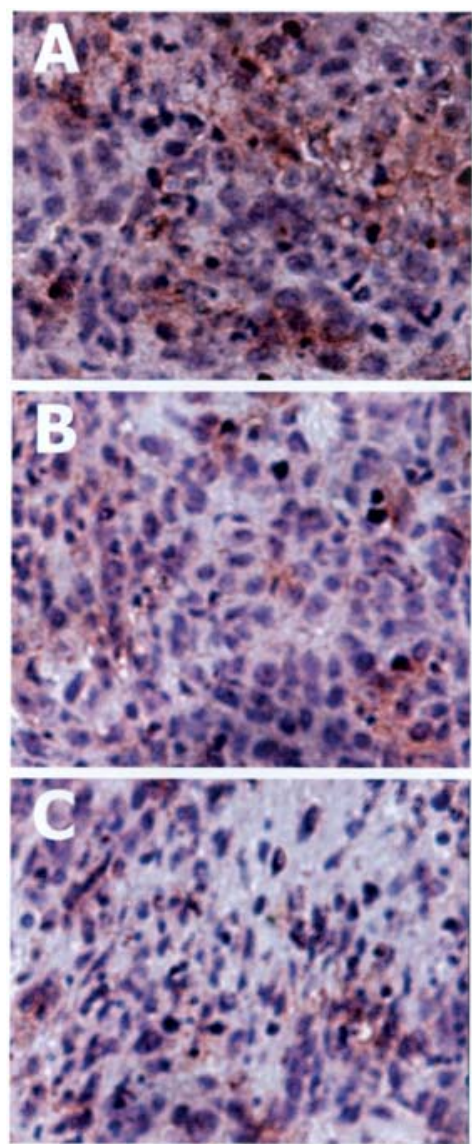

Figure 5. Immunohistochemistry for MMP-2 expression in tumor xenografts in Balb/c athymic (nu+/nu+) mice administered LY52. Nude mice were implanted with MDA-MB-231 cells and orally administered 0 (A), 25 (B), and $100(\mathrm{C}) \mathrm{mg} / \mathrm{kg}$ of LY52. After 30 days, the tissues of tumor xenografts were subjected to immunohistochemistry to detect MMP-2 as described in Materials and methods. Original magnification, x200.

Table I, the number of tumor nodules on the lung surface was significantly lower in LY52-treated mice than in untreated mice $(\mathrm{p}<0.05)$. The anti-metastasis ability of LY52 was dosedependent. In contrast, a significant weight loss was not observed during continuous administration (Table I).

\section{Discussion}

This study assessed the LY52, a caffeoyl pyrrolidine derivative, as a gelatinase inhibitor in inhibiting tumor invasion and metastasis. LY52 effectively inhibited MMP-2 activity in vitro (Fig. 2). LY52 also suppressed active MMP-2 expression in MDA-MB-231 cells in vitro (Fig. 4) and in vivo (Fig. 5), while the compound did not display a significant anti-proliferative effect or cytotoxicity (Fig. 3). Furthermore, the invasive capacity of Con A-stimulated MDA-MB-231 cells to cross a matrigel layer was effectively diminished in the presence of LY52 (Fig. 6).

Of the gelatinases, MMP-2 is highly expressed in invasive and metastatic carcinoma tissues, while the enzyme is usually absent in normal tissue (21-23). Expression and activity of MMP-2 are tightly regulated. Cancer cells secrete MMP-2 as a $72-\mathrm{kDa}$ pro-MMP on the cell surface and require specific

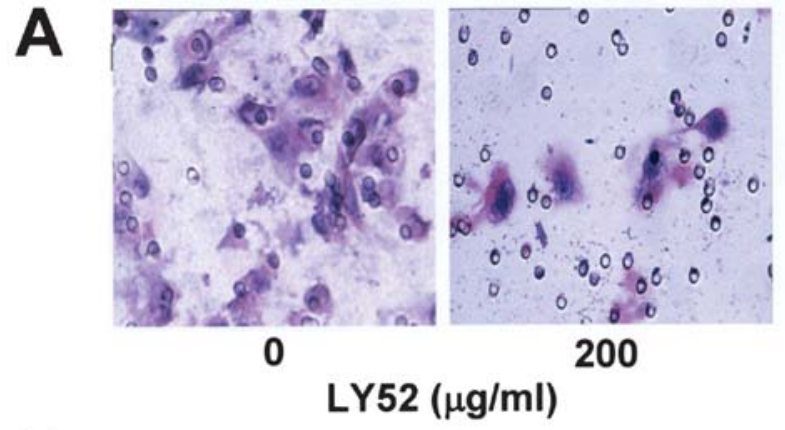

B

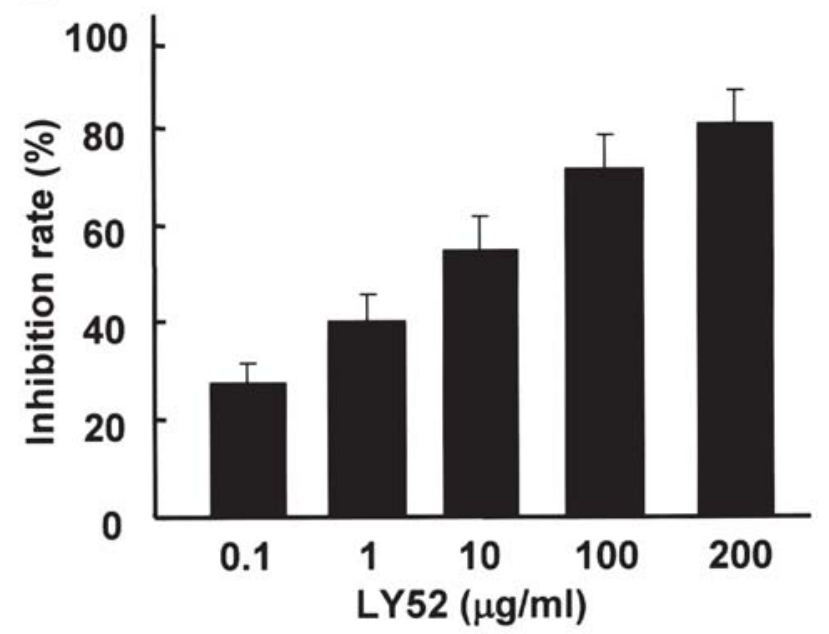

Figure 6. Inhibition of MDA-MB-231 cell invasion by LY52. Cells pre-treated with various concentrations of LY52 were placed on Matrigel-coated filters and incubated for $24 \mathrm{~h}$. The number of cells passing through the filter was calculated after staining with hematoxylin. (A) Typical micrographs of invading MDA-MB-231 cells pre-treated without or with $200 \mu \mathrm{g} / \mathrm{ml}$ of LY52. Original magnification, $x 400$. (B) Rates of inhibition of cell invasion by various concentrations of LY52. Data are mean $\pm \operatorname{SD}(n=6)$.

activation by proteolytic removal of the $\mathrm{NH} 2$-terminal propeptide for conversion to the 62-kDa active form (24-26). Similarly to most invasive human breast cancer cell lines, MDA-MB-231 cells can be induced to activate exogenous MMP-2 when the cells are treated with Con A (15). Con A may stimulate membrane type $1 \mathrm{MMP}$ (MT1-MMP) to cleave the N-terminal prodomain in MMP-2 (10,25-27). In the present study, LY52 had an inhibitory effect on invasion of MDA-MB-231 cells in vitro (Fig. 6). Since the highly invasive potential of MDA-MB-231 cells is dependent on the activation of exogenous MMP-2 (15) and since only VIM+ cell lines can be induced to activate MMP-2 upon stimulation with Con A $(10,28)$, the anti-invasion ability of LY52 might be due to the inhibition of active MMP-2 expression. In addition, $\mathrm{IC}_{50}$ values of LY52 were clearly similar for active MMP-2 expression and cell invasion in Con A-stimulated MDA-MB-231 cells, suggesting that LY52 may suppress cell invasion through inhibition of the expression of active MMP-2.

Examination of the anti-metastatic ability of LY52 in vivo was performed with metastatic B16F10 melanoma cells instead of MDA-MB-231 cells. B16F10 cells overexpressing MMP-2 in vivo are known to be more likely to develop 
Table I. Effect of LY52 on B16-F10 melanoma metastasis in C57/BL6 mice.

\begin{tabular}{lcccccc}
\hline Compound & $\begin{array}{c}\text { Dosage } \\
(\mathrm{mg} / \mathrm{kg})\end{array}$ & $\begin{array}{c}\text { Mice } \\
(\mathrm{n})\end{array}$ & $\begin{array}{c}\text { Body weight } \\
(\mathrm{g})\end{array}$ & $\begin{array}{c}\text { Lung weight } \\
(\mathrm{g})\end{array}$ & $\begin{array}{c}\text { Number of } \\
\text { foci/lung }(\mathrm{n})\end{array}$ & $\begin{array}{c}\text { Inhibition of } \\
\text { metastasis }(\%)\end{array}$ \\
\hline LY52 & 0 & 10 & $22.6 \pm 2.9$ & $0.13 \pm 0.03$ & $88.6 \pm 15.7$ & - \\
& 25 & 9 & $23.1 \pm 3.2$ & $0.12 \pm 0.08$ & $65.0 \pm 10.3^{\mathrm{a}}$ & 24.4 \\
& 50 & 10 & $21.7 \pm 2.2$ & $0.12 \pm 0.03$ & $49.1 \pm 13.5^{\mathrm{b}}$ & 43.5 \\
Carboxylates & 100 & 10 & $21.3 \pm 3.7$ & $0.12 \pm 0.06$ & $35.3 \pm 8.7^{\mathrm{b}}$ & 60.2 \\
\hline
\end{tabular}

${ }^{\mathrm{a}} \mathrm{p}<0.05,{ }^{\mathrm{b}} \mathrm{p}<0.01$ vs. untreated group.

pulmonary metastases, and cellular invasiveness is known to depend on the functional consequences of increased MMP-2 levels (29). The present study showed that oral administration of LY52 significantly prevented the pulmonary metastasis of B16F10 cells in mice devoid of toxic effects. These results suggest that LY52 may inhibit the metastasis of melanoma cells by blocking active MMP-2 expression.

LY52 was designed based on the analogue reference drug CGS27023A $(8,9)$, a broad-spectrum MMP inhibitor that inhibits the activity and expression of MMP-1, 2, 3, and 9 (30-32). The characteristic broad spectrum may correlate to its larger structure, which accommodates the $S^{\prime}{ }_{1}$ pocket of MMP-3 $(3,8,9)$. Since the $S_{1}^{\prime}$ pocket of gelatinase is deeper than that of MMP-3, we designed a backbone of hydroxyproline linked with the longer and flexible caffeoyl group to extend into the deeper $S_{1}^{\prime}$ pocket $(8,9)$. Hydroxyproline is known to be a specific amino acid of collagens, which are the substrate of MMPs (8). Caffeic acid has been proven to inhibit the activity of MMP-2 and -9 (33). The p-(methylphenyl) sulfonyl group can extend into the $S_{1}^{\prime}$ active pocket of MMP-2 and -9 , which may enhance the flexibility of the chemical structure to combine with the active site $(8,9)$. Carboxylic acid, a metabolized product of carbomethoxy derivatives, might chelate zinc ions, which are essential to enzyme activity $(8,9)$. These structures in the LY52 molecule might improve selectivity with respect to gelatinases such as MMP-2.

In conclusion, LY52 is a novel caffeoyl pyrrolidine derivative with an inhibitory effect on the expression and activity of MMP-2. Administration of LY52 in mice prevented MMP-2 expression in tumor xenografts and pulmonary metastasis of melanoma cells without any significant toxicity. These results suggest that LY52 is a potential MMP-2 inhibitor and a candidate compound for preventing tumor invasion and metastasis.

\section{Acknowledgements}

This study was supported by the National Natural Science Foundation of China (30472038), and the Japan-China Medical Association, Tokyo, Japan. We wish to thank the Bureau of Personnel of Shandong Province for their support of this study at the University of Tokyo, and Professor Yoko Yamaguchi and Dr Keiko Sakai, Tokai University, Kanagawa, Japan, for their advice.

\section{References}

1. Rundhaug JE: Matrix metalloproteinases and angiogenesis. J Cell Mol Med 9: 267-285, 2005.

2. Wang J, Levenson AS and Satcher RL Jr: Identification of a unique set of genes altered during cell-cell contact in an in vitro model of prostate cancer bone metastasis. Int J Mol Med 17: 849-856, 2006.

3. Gonnella NC, Li YC, Zhang X and Paris CG: Bioactive conformation of a potent stromelysin inhibitor determined by $\mathrm{X}$-nucleus filtered and multidimensional NMR spectroscopy. Bioorg Med Chem 5: 2193-2201, 1997.

4. Rowsell S, Hawtin P, Minshull CA, Jepson H, Brockbank SM, Barratt DG, Slater AM, McPheat WL, Waterson D, Henney AM and Pauptit RA: Crystal structure of human MMP9 in complex with a reverse hydroxamate inhibitor. J Mol Biol 319: 173-181, 2002.

5. Kiyama R, Tamura Y, Watanabe F, Tsuzuki H, Ohtani M and Yodo M: Homology modeling of gelatinase catalytic domains and docking simulations of novel sulfonamide inhibitors. J Med Chem 42: 1723-1738, 1999.

6. Fernandez-Catalan C, Bode W, Huber R, Turk D, Calvete JJ, Lichte A, Tschesche H and Maskos K: Crystal structure of the complex formed by the membrane type 1-matrix metalloproteinase with the tissue inhibitor of metalloproteinases-2, the soluble progelatinase A receptor. EMBO J 17: 5238-5248, 1998.

7. Rossello A, Nuti E, Orlandini E, Carelli P, Rapposelli S, Macchia M, Minutolo F, Carbonaro L, Albini A, Benelli R, Cercignani G, Murphy G and Balsamo A: New N-arylsulfonyl$\mathrm{N}$-alkoxyaminoacetohydroxamic acids as selective inhibitors of gelatinase A (MMP-2). Bioorg Med Chem 12: 2441-2450, 2004.

8. Li YL and Xu WF: Design, synthesis, and activity of caffeoyl pyrrolidine derivatives as potential gelatinase inhibitors. Bioorg Med Chem 12: 5171-5180, 2004.

9. Li X, Li Y and $\mathrm{Xu} \mathrm{W}$ : Design, synthesis, and evaluation of novel galloyl pyrrolidine derivatives as potential anti-tumor agents. Bioorg Med Chem 14: 1287-1293, 2006.

10. Pulyaeva H, Bueno J, Polette M, Birembaut P, Sato H, Seiki M and Thompson EW: MT1-MMP correlates with MMP-2 activation potential seen after epithelial to mesenchymal transition in human breast carcinoma cells. Clin Exp Metastasis 15: 111-120, 1997.

11. Qu XJ, Yang JL, Russell PJ and Goldstein D: Changes in epidermal growth factor receptor expression in human bladder cancer cell lines following interferon-alpha treatment. J Urol 172: 733-738, 2004

12. Baragi VM, Shaw BI, Renkiewicz RR, Kuipers PJ, Welgus HG, Mathrubutham M, Cohen JR and Rao SK: A versatile assay for gelatinases using succinylated gelatin. Matrix Biol 19: 267-273, 2000 .

13. Yucel T, Mutnal A, Fay K, Fligiel SE, Wang T, Johnson T, Barker SR and Varani J: Matrix metalloproteinase expression in basal cell carcinoma: relationship between enzyme profile and collagen fragmentation pattern. Exp Mol Pathol 79: 151-160, 2005 . 
14. Souza-Tarla CD, Uzuelli JA, Machado AA, Gerlach RF and Tanus-Santos JE: Methodological issues affecting the determination of plasma matrix metalloproteinase (MMP)-2 and MMP-9 activities. Clin Biochem 38: 410-414, 2005.

15. Yu M, Sato H, Seiki M, Spiegel S and Thompson EW: Calcium influx inhibits MT1-MMP processing and blocks MMP-2 activation. FEBS Lett 412: 568-572, 1997.

16. Cui SX, Qu XJ, Xie YY, Zhou L, Nakata M, Makuuchi M and Tang W: Curcumin inhibits telomerase activity in human cancer cell lines. Int J Mol Med 18: 227-231, 2006.

17. Tang W, Inagaki Y, Kokudo N, Guo Q, Seyama Y, Nakata M, Imamura H, Sano K, Sugawara Y and Makuuchi M: KL-6 mucin expression in carcinoma of the ampulla of Vater: association with cancer progression. World J Gastroenterol 11: 5450-5454, 2005.

18. Tian B, Li Y, Ji XN, Chen J, Xue Q, Ye SL, Liu YK and Tang ZY: Basement membrane proteins play an active role in the invasive process of human hepatocellular carcinoma cells with high metastasis potential. J Cancer Res Clin Oncol 131: 80-86, 2005.

19. Chang WW, Yu CY, Lin TW, Wang PH and Tsai YC: Soyasaponin I decreases the expression of alpha2, 3-linked sialic acid on the cell surface and suppresses the metastatic potential of B16F10 melanoma cells. Biochem Biophs Res Commun 341: 614-619, 2006.

20. Kontogiorgis CA, Papaioannou P and Hadjipavlou-Litina DJ: Matrix metalloproteinase inhibitors: a review on pharmacophore mapping and (Q) SARs results. Curr Med Chem 12: 339-355, 2005.

21. Mendes O, Kim HT and Stoica G: Expression of MMP2, MMP9 and MMP3 in breast cancer brain metastasis in a rat model. Clin Exp Metastasis 22: 237-246, 2005.

22. Onisto M, Slongo ML, Gregnanin L, Gastaldi T, Carli M and Rosolen A: Expression and activity of vascular endothelial growth factor and metalloproteinases in alveolar and embryonal rhabdomyosarcoma cell lines. Int J Oncol 27: 791-798, 2005.

23. Gao ZB, Duan YQ, Zhang L, Chen DW and Ding PT: Expression of matrix metalloproteinase 2 and its tissue inhibitor in oral squamous cell carcinoma. Int J Mol Med 16: 599-603, 2005.

24. Haupt LM, Thompson EW, Trezise AE, Irving RE, Irving MG and Griffiths LR: In vitro and in vivo MMP gene expression localization by In Situ-RT-PCR in cell culture and paraffin embedded human breast cancer cell line xenografts. BMC Cancer 6: 18, 2006.
25. Gilles C, Polette M, Seiki M, Birembaut $\mathrm{P}$ and Thompson EW: Implication of collagen type I-induced membrane-type 1-matrix metalloproteinase expression and matrix metalloproteinase-2 activation in the metastatic progression of breast carcinoma. Lab Invest 76: 651-660, 1997.

26. Deryugina EI, Ratnikov B, Monosov E, Postnova TI, DiScipio R, Smith JW and Strongin AY: MT1-MMP initiates activation of proMMP-2 and integrin alphavbeta3 promotes maturation of MMP-2 in breast carcinoma cells. Exp Cell Res 263: 209-223, 2001.

27. Bartsch JE, Staren ED and Appert HE: Matrix metalloproteinase expression in breast cancer. J Surg Res 110: 383-392, 2003.

28. Szabo KA and Singh G: Modulation of monocyte matrix metalloproteinase- 2 by breast adenocarcinoma cells. Breast Cancer Res 7: R661-R668, 2005.

29. Philip S, Bulbule A and Kundu GC: Osteopontin stimulates tumor growth and activation of promatrix metalloproteinase-2 through nuclear factor-kappa B-mediated induction of membrane type 1 matrix metalloproteinase in murine melanoma cells. J Biol Chem 276: 44926-44935, 2001.

30. Levitt NC, Eskens F A, O'Byrne KJ, Propper DJ, Denis LJ, Owen SJ, Choi L, Foekens JA, Wilner S, Wood JM, Nakajima M, Talbot DC, Steward WP, Harris AL and Verweij J: Phase I and pharmacological study of the oral matrix metalloproteinase inhibitor, MMI270 (CGS27023A), in patients with advanced solid cancer. Clin Cancer Res 7: 1912-1922, 2001.

31. Eatock M, Cassidy J, Johnson J, Morrison R, Devlin M, Blackey R, Owen S and Twelves C: A dose-finding and pharmacokinetic study of the matrix metalloproteinase inhibitor MMI270 (previously termed CGS27023A) with 5-FU and folinic acid. Cancer Chemother Pharmacol 55: 39-46, 2005.

32. Baba M, Itoh K and Tatsu M: Glycine-extended gastrin induces matrix metalloproteinase-1- and -3-mediated invasion of human colon cancer cells through type I collagen gel and Matrigel. Int J Cancer 111: 23-31, 2004.

33. Feng X, Danqing S and Yongsu Z: Discussion of the Inhibition of Angiogenesis and its Mechanism. In: Progress of Antineoplasm-drugs and Chemotherapy. Beijing Science Publ. Corp. p243, 2001. 